proved to be suitable as substitution therapy in hypocoagulability. Traumatic hemorrhagic shock was successfully treated with fresh-frozen plasma in 25 patients.

Key words: Coagulopathy - Shock, hemorrhagic - Heparin - Plasma, fresh-frozen.

Zusammenfassung. Die Gerinnungsstörung im Blutungsschock ist komplexer Natur und bedingt durch intravasale Gerinnung, extravasalen Verlust, Verdünnung und mangelnde Synthese von Gerinnungsfaktoren. Heparin ist kontraindiziert, weil es die Hypokoagulobilität und damit Blutung und Schock nicht unterbricht. Tiefgefroren konserviertes Frischplasma dagegen hat sich uns zur Substitutionstherapie der Hypokoagulobilität bewährt. 25 Patienten im traumatisch-hämorrhagischen Schock wurden mit tiefgefroren konserviertem Frischplasma erfolgreich behandelt.

Schlïsselwörter: Intravasale Gerinnung - Hämorrhagischer Schock - Heparin - Tiefgefrorenes Frischplasma.

\title{
85. Strahlenbelastung bei percutanen Osteosynthesen
}

\author{
G. Kramer \\ Unfallchirurgische Klinik der Städt. Kliniken Dortmund
}

\section{Radiation Exposure during Percutaneous Osteosynthesis}

Summary. A screening time of $4.08 \mathrm{~min}$ is average for percutaneous internal fixation, according to measurements recorded during 173 percutaneous operations for internal fixation. The mean radiation exposure for the operator was $1.37 \mathrm{mr}$ per minute; $100 \mathrm{mr}$ per week is the tolerance dose for any person working with X-rays. Thus about $70 \mathrm{~min}$ of screening time is tolerable. All other persons in the operating team had lower levels. Special monitoring is only necessary for the operator, the assistant surgeon and the theater nurse assisting at the operation.

Key words: Osteosynthesis percutaneous - Radiation exposure.

Zusammenfassung. Bei 173 percutanen Osteosynthesen wurde eine mittlere Durchleuchtungszeit von 4,08 min pro Operation ermittelt. Die Strahlenbelastung des Operateurs beträgt im Mittel 1,37 mr pro min. Die Toleranzdosis liegt bei ca. $100 \mathrm{mr}$ pro Woche. Rund $70 \mathrm{~min}$ Durchleuchtungszeit wären demnach zumutbar. Alle anderen Personen des Op.-Teams bleiben unter diesen Werten. Die Überwachung des Personals ist nach unseren Untersuchungen auf Operateur, Durchleuchter, Instrumentenschwester zu beschränken.

Schlïsselwörter: Percutane Osteosynthesen - Strahlenbelastung. 